\title{
Prechod administratívnoprávnej zodpovednosti na právneho nástupcu právnickej osoby
}

\author{
Succession of Administrative Liability \\ onto Legal Successor of Legal Person
}

\author{
Matej Horvat ${ }^{*}$
}

\begin{abstract}
Abstrakt
Príspevok sa venuje prechodu administrativnoprávnej zodpovednosti na právneho nástupcu právnickej osoby. Analyzuje danú tému z viacerých hl'adísk. V prvej časti príspevku je pozornost' venovaná východiskám prechodu zodpovednosti, ak ide o právnické osoby. Popisuje preto pôvod myšlienok tobto inštitútu z angloamerickébo právneho systému a ich prechod do kontinentálneho právneho systému a osvetliuje problematiku respondeat superior. $V$ drubej časti sa analyzujú možnosti prechodu administrativnoprávnej zodpovednosti na právneho nástupcu právnickej osoby v krajinách V4 s osobitným zretelom na České republiku, pretože v tejto krajine je tento inštitút aj inštitútom de lege lata. V tretej časti je pozornost' venovaná téme u气̌ z.pobladu Slovenka, kede sa s týmto inštitútom stretla právna prax a existuje k nemu aj relevantná súdna judikaturra. $Z$ pobladu de lege lata je však prechod zodpovednosti riešený len v trestnom práve a nie v správnom práve. V poslednej cásti príspevku venuje autor pozornost' legislativnemu návrbu, ako by mohol byt' prechod zodpovednosti upravený v právnych predpisoch Slovenskej republiky. Tieto návrby de lege ferenda predstavijú syntézu poznatkov z.predchádzajúcich častí tobto článku.
\end{abstract}

\section{Klíčová slova}

Zodpovednost; právna zodpovednost; respondeat superior; prechod zodpovednosti; prechod právnej zodpovednosti na právneho nástupcu právnickej osoby; prechod právnej zodpovednosti v správnom práve krajín V4; prechod práunej zodpovednosti de lege ferenda.

\begin{abstract}
The paper deals with the succession of administrative liability onto the legal successor of a legal person. It analyses the topic from several points of view. In the first part of the paper, the attention is paid to the basic facts on the succession of liability of legal persons. Therefore, it describes the origin of the ideas of this legal institute from the Anglo-American legal system and their transition to the continental legal system and explains respondeat superior theory. The second part of the article analyses the possibilities of the succession of administrative liability onto the legal successor of a legal person in the V4 countries with special regard to the Czech Republic, because in this country this institute is enacted as an institute de lege lata. The third part of the article is devoted to the topic from the perspective of Slovakia, where legal practice used this legal institute and therefore is recognized by relevant judicial case law too. However, from de lege lata point
\end{abstract}

\footnotetext{
Doc. JUDr. Matej Horvat, PhD., Katedra správneho a environmentálneho práva, Právnická fakulta, Univerzita Komenského v Bratislave, Slovenská republika / Department of Administrative Law and Environmental Law, Faculty of Law, Comenius University in Bratislava, Slovak Republic / E-mail: matej. horvat@flaw.uniba.sk / ORCID: 0000-0002-8249-4029
} 
of view, only criminal law deals with the succession of liability of legal persons and not administrative law. In the last part of the article, the attention is paid to a legislative proposal on how the succession of liability could be regulated in the legislation of Slovak. Republic. These de lege ferenda proposals represent a synthesis of the text from the previous parts of the article.

\section{Keywords}

Accountability; Liability; Respondeat Supeorior; Succession of Liability; Succession of Liability onto Legal Successor of Legal Person; Succession of Liability in Administrative Law of V4 Countries; Succession of Liability de lege ferenda.

\section{Úvod}

Pri výbere témy tohto článku zohralo úlohu viacero faktorov. Prechod administratívnoprávnej zodpovednosti na právneho nástupcu právnickej osoby je hraničnou problematikou, ktorá sa dá skúmat' z pohladu viacerých právnych odvetví. Autor preto musí preukázat' schopnost' orientovat' sa v nich a zároveň preukázat' schopnost' argumentovat', analyzovat', komparovat', či vytvárat' syntézy myšlienok tak, aby boli jeho závery akceptovatel'né naprieč týmito právnymi odvetviami. Navyše, tému prechodu (administratívnej) zodpovednosti je nad'alej témou, ktorá je aktuálna a, dovolím si dokonca tvrdit', aj kontroverzná, ako sa pokúsim v rámci príspevku preukázat'.

Z obsahového hladiska sa budem venovat' viacerým okruhom spojeným s vyvodzovaním zodpovednosti voči právnemu nástupcovi právnickej osoby, a to konkrétne pôvodu myšlienok o prechode zodpovednosti na právneho nástupcu právnickej osoby, prechodu zodpovednosti na právneho nástupcu právnickej osoby v krajinách V4, analýze právneho stavu v Slovenskej republike a napokon návrhom de lege ferenda $\mathrm{v}$ tejto oblasti pre slovenského zákonodarcu.

$\mathrm{V}$ rámci príspevku budem využívat' viaceré metódy vedeckého výskumu, ktoré zodpovedajú kritériám, ktoré som spomenul v predchádzajúcom texte. Pôjde predovšetkým o metódu analýzy, ktorú využijem pri analýze súčasného právneho stavu možnosti prechodu administratívnoprávnej (ale aj trestnoprávnej) zodpovednosti na právneho nástupcu právnickej osoby, d’alej metódu komparácie, ktorú využijem pri porovnávaní kontinentálneho právneho systému a angloamerického právneho systému, ako aj pri komparácii právnej úpravy krajín V4 a v rámci slovenskej právnej úpravy aj pri trestnoprávnych a správnoprávnych názoroch na prechod zodpovednosti na právneho nástupcu právnickej osoby. Syntéza ako metóda vedeckého výskumu bude využívaná najmä v závere článku, kde budem formulovat’ viaceré odporúčania de lege ferenda k zvolenej téme.

\section{Východiská prechodu zodpovednosti na právneho nástupcu právnickej osoby $\mathrm{v}$ angloamerickom a kontinentálnom právnom systéme}

Nie je žiadnym tajomstvom, ked’ uvediem, že prechod právnej zodpovednosti na právneho nástupcu právnickej osoby $\mathrm{v}$ kontinentálnom verejnom práve je konceptom relatívne novým. Relatívna novost' myšlienok o prechode zodpovednosti vychádza 
predovšetkým z faktu, že prechod zodpovednosti bol a nad’alej aj je predovšetkým konceptom, ktorý sa vyvinul $\mathrm{v}$ angloamerickej právnej kultúre. Kontinentálny právny systém bol v tomto smere (a v niektorých štátoch to aj nad'alej platî) konzervatívnejší - vybudovaný na myšlienke societas delinquere non potest, ${ }^{1}$ prípadne sa v ňom zdôrazňovala zásada individuálnej trestnej zodpovednosti. ${ }^{2}$ Podstatou spomenutej myšlienky, ktorej prvopočiatky siahajú až do čias Rímskeho impéria, je, že právnická osoba nemôže spáchat' žiadne delikty, a preto nemôže byt' za ne sankcionovaná. ${ }^{3}$

Som toho názoru, že ak chceme analyzovat’ prechod právnej zodpovednosti na právneho nástupcu právnickej osoby, je nevyhnutné poznat' aj myšlienky, ktoré viedli práve $\mathrm{k}$ „odstráneniu“ premisy sociatas delinquere non potest $\mathrm{v}$ našom právnom systéme.

Ako som spomenul, tak kontinentálny právny systém bol po dlhú dobu spätý s touto myšlienkou. $\mathrm{Na}$ druhej strane angloamerický právny systém túto otázku vyriešil ovel’a skôr. V literatúre sa uvádza, že ešte na začiatku 18. storočia (1701) súdne precedensy vychádzali z myšlienky, podl’a ktorej korporácia ${ }^{4}$ (teda právnická osoba v dnešnom ponímaní pozn. autora) nemôže byt' trestaná, ale jej jednotliví členovia áno. ${ }^{5}$ Zároveň však od 17 . storočia začali právnické osoby výrazným spôsobom zasahovat' do každodenného života. Ich sila premenila najmä z toho dôvodu, že akumulovali finančný profit získaný predovšetkým z koloniálnej éry vtedajšej Európy. Na druhej strane zároveň mnohé z týchto spoločností boli zapojené do protiprávnych praktík ako napríklad podplácanie a podvody, pričom mnohé mali krátku životnost’; hovorilo sa, že praskajú ako „,bubliny na vode“. Z daného dôvodu bol v Anglicku prijatý tzv. Bublinový zákon (1720), ktorý, namiesto zavedenia zodpovednosti za konanie týchto spoločností, jednoducho možnost’ vytvárania týchto spoločností vyhlásil za protizákonné a neplatné. Ked’že tento stav v následnom historickom vývoji znamenal prekážku ekonomického rozvoja, tento zákon bol v roku 1825 zrušený. ${ }^{6}$

Už od polovice 19. storočia začali súdy ponímat' právnické osoby ako subjekty, ktoré podliehajú vyvodeniu zodpovednosti. Korporácie sa stali dominantnejšími v spoločnosti a ich potenciál spôsobit' výrazné škody verejnosti vzrástol. Súdy preto začali regulovat' a trestat'

1 Z latinčiny spoločnost' nemôže spáchat' zločin.

2 Pozri napríklad MENCEROVÁ, I. In: TURAYOVÁ, Y., L. TOBIÁŠOVÁ, J. ČENTÉŠ a kol. Trestná zodpovednost' právnických osôb. Vybrané aspekty trestnej zodpovednosti právnickéch osôb v SR. Bratislava: Wolters Kluwer, 2016, s. 53.

3 ŠIMOVČEK, I. a E. SZABOVÁ. In: MASLEN, M. a N. HRNČÁROVÁ (eds.). Trestnoprávna a administrativnoprávna zodpovednost'. Trnava: Typi Universitatis Tyrnaviensis, 2014, s. 257.

4 V celom texte budem používat' pojmy korporácia a právnická osoba ako synonymické.

5 Myšlienka je citovaná $\mathrm{z}$ anonymnej zbierky súdnych rozhodnutí z roku 1701; citované podl’a WONG, K. Breaking the Cycle. The Development of Corporate Criminal Liablity. Záverečná práca. Dunedin: University of Otago, 2012, s. 8. Dostupné z: https://www.otago.ac.nz/law/research/journals/otago041733.pdf [cit. 12. 10. 2019].

6 BASSI, A. Corporate Criminal Liability. An Analytical Study with Special Reference to Penal Laws in India. Dizertačná práca. Patiala: Rajiv Gandhi National University of Law, 2016, s. 41. Dostupné z: http:// shodhganga.inflibnet.ac.in/handle/10603/200004 [cit. 12. 10. 2019]. 
spoločnosti za verejné nepríjemnosti ako napríklad poškodené cesty (Commonwealth vs. Hancock Free Bridge Corp, 1854), poškodené mosty (State vs. Morris Canal \& Banking Co., 1850) či znečist'ovanie povodia rieky (People vs. Corporation of Albany, 1834). Verejnoprávne vymáhanie bolo nevyhnutné, pretože iba málo l'udí malo vôl'u a schopnosti vymáhat' dodržanie práva prostriedkami súkromného práva. Súkromnoprávne vymáhanie si totiž vyžadovalo preukázat' spáchanie konkrétnej škody, pričom však spomenuté verejné nepríjemnosti dopadali skôr na spoločnost' ako takú, než na konkrétnu jednu osobu. ${ }^{7}$

V podstate obdobný vývoj možno zaznamenat’ aj v Spojených štátoch amerických. Pre územie tohto štátu je v tejto súvislosti významným precedentným rozhodnutím na federálnej úrovni prípad New York Central \& Hudson River Railroad Company vs. United States (1909). V danom rozhodnutí Najvyšší súd USA vychádzal z „,verejnej politiky“ a moci, ktorú v „moderných časoch“ korporácie majú, a preto ponechal v platnosti federálny zákon, ktorý trestal právnické osoby. Súd nielenže uznal, že Kongres môže prijat’ zákon, ktorý trestá právnické osoby, ale dokonca túto možnost' posvätil. (...) Súd povedal, že existujú zločiny, ktoré vo svojej podstate môžu byt' spáchané korporáciami. ${ }^{8}$ Význam uvedeného rozhodnutia spočíva najmä $\mathrm{v}$ tom, že odmietol predchádzajúcu doktrínu o nemožnosti vyvodenia zodpovednosti voči právnickým osobám; označil ju za prekonanú. Navyše, išlo o rozhodnutie na federálnej úrovni, a teda podl’a uvedeného rozhodnutia začali interpretovat’ právo aj ostatné súdne inštitúcie.

Čo je vel'mi zaujímavé, je skutočnost', že súdy v angloamerickom právnom systéme pri tvorbe konceptu zodpovednosti právnickej osoby vo verejnom práve (osobitne trestnom práve) vychádzali z doktríny respondeat superior, čo je však pôvodne doktrína súkromného práva.

Respondeat superior je forma objektívnej zodpovednosti a považuje sa za akúsi odnož tzv. zástupnej (sprostredkovanej) zodpovednosti (vicarious liability). Respondeat superior predstavuje latinské vyjadrenie pojmu „nech zodpovedá pán“ (,let the master answer"), niekedy sa zvykne označovat’ aj pojmami „pán a sluha“ („master and servant”), prípadne v medicínskom prostredí aj pojmom „kapitán lode“ (,captain of the ship“). ${ }^{11}$

7 Porovnaj a pozri bližšie WONG, K. Breaking the Cycle. The Development of Corporate Criminal Liablity. Záverečná práca. Dunedin: University of Otago, 2012, s. 8-9. Dostupné z: https://www.otago.ac.nz/ law/research/journals/otago041733.pdf [cit. 12. 10. 2019].

8 ALSCHUler, A. W. Two Ways to Think about the Punishment of Corporations. In: American Criminal Law Review, 2009, roč. 46, s. 1363. Dostupné z: https://scholarlycommons.law.northwestern.edu/cgi/ viewcontent.cgi? referer $=\&$ httpsredir $=1 \&$ article $=1191 \&$ context $=$ facultyworkingpapers [cit. 12. 10. 2019].

9 NANDA, V. P. Corporate Criminal Liability in the United States: Is a New Approach Warranted? In: PIETH, M. a R. IVORY. Corporate Criminal Liability: Emergence, Convergence, and Risk. Springer, 2011, s. 65. Dostupné z: https://books.google.sk/books?id=-o2ycT3hWccC\&\&pg=PR7\&\&hl=cs\&\&sour$\mathrm{ce}=$ gbs_selected_pages\&\&cad=3 [cit. 12.10.2019].

10 ENCYCLOPAEDIA BRITANNICA. Respondeat superior. Dostupné z: https://www.britannica.com/ topic/respondeat-superior [cit. 13. 10. 2019].

11 TANGEMAN, M. J. (ed.). Judicial Council of California. Civil Jury Instructions, s. 496. Dostupné z: https:// www.justia.com/documents/trials-litigation-caci.pdf [cit. 13.10.2019]. 
Podstata tejto doktríny (ako som spomenul pôvodne súkromného práva) spočíva v tom, že zamestnávatel je sprostredkovane zodpovedný za delikt, ktorý spáchal jeho zamestnanec $v$ rámci výkonu svojho zamestnania. ${ }^{12}$ Táto doktrína sa aj dnes využíva v oblasti pracovného práva, avšak tiež sa d’alej využíva napríklad aj v medicínskom prostredí (zodpovednost' operujúceho doktora) a v oblasti sexuálneho obt'ažovania na pracovisku. ${ }^{13}$ Uvádza sa, že zamestnávatel' je zodpovedný za konanie zamestnanca, ktorým došlo k vzniku škody, ktorá bola spôsobená zamestnávatel'ovou nedbanlivost'ou alebo opomenutím konania (t. j. nedostatok dohl'adu a kontroly nad zamestnancom, ktorý tu mal byt'). Respondeat superior tak medzi riadkami predstavuje „cenu“, ktorú za spáchanie deliktu $\mathrm{v}$ súvislosti s podnikatel'skou činnost'ou musí niest' korporácia; ide o jedno z rizík podnikania. ${ }^{14}$

Najvýznamnejšie zdôvodnenie využitia doktríny respondeat superior aj vo vzt'ahu k deliktnému právu spočíva $\mathrm{v}$ tom, že v priebehu vývoja práva a spoločnosti získavali korporácie mnohé výhody podobné postaveniu fyzických osôb, ale zároveň im bola zachovaná možnost' skryt' sa za komplex korporátnej štruktúry s ciel'om vyhnút' sa zodpovednosti podl'a trestného práva. ${ }^{15}$ Doktrína respondeat superior je teda reakciou na tento neuspokojivý stav.

Vytvorená súdmi prostredníctvom common law systému, doktrína trestnej zodpovednosti právnických osôb má svoj základ v súkromnoprávnej doktríne respondeat superior. Princíp zástupnej (sprostredkovanej) trestnej zodpovednosti sa aplikuje tak, že objektívna stránka (actus reus), teda čin, ktorý je zákonom zakázaný a subjektívna stránka, čiže zavinenie (mens rea) jednotlivca, ktorý konal v mene právnickej osoby, je automaticky pričítaný právnickej osobe. A teda, ak zamestnanec alebo splnomocnenec právnickej osoby spácha trestný čin konaním, prikázaním alebo opomenutím konania a koná tak v súvislosti s výkonom svojho zamestnania a tento výkon je aspoň sčasti na prospech právnickej osoby, právnická osoba je trestne zodpovedná. Avšak obe tieto podmienky, teda to, že zamestnanec musel konat' $v$ rámci svojho zamestnania a že jeho konanie muselo byt' na prospech právnickej osoby, sú súdmi interpretované pomerne široko. Dôsledkom je, že federálne súdy vychádzajú z toho, že konanie zamestnanca na akomkol’vek nízkom stupni riadenia môže byt' pričítané právnickej osobe, a to aj bez ohl'adu na to, ako

12 Pozri precedens Perez vs. Van Groningen \& Sons, Inc. (1986).

13 Pozri TANGEMAN, M. J. (ed.). Judicial Council of California. Civil Jury Instructions, s. 496 a nasl. a s. 1530 a nasl. Dostupné z: https://www.justia.com/documents/trials-litigation-caci.pdf [cit. 13. 10. 2019].

14 Porovnaj THORTON, R. G. Responsibility for the Acts of Others. In: US National Library of Medicine. National Institutes of Health. Dostupné z: https://www.ncbi.nlm.nih.gov/pmc/articles/PMC2900989/ [cit. 15. 10.2019].

15 WONG, K. Breaking the Cycle. The Development of Corporate Criminal Liablity. Záverečná práca. Dunedin: University of Otago, 2012, s. 12. Dostupné z: https://www.otago.ac.nz/law/research/journals/ otago041733.pdf [cit. 15. 10. 2019]. 
efektívny má táto osoba vytvorený compliance program využitel'ný na predchádzanie trestnej činnosti - právnická osoba je aj napriek tomu zodpovedná. ${ }^{16}$

Čo je teda vel'mi zaujímavé, je skutočnost', ako sa táto doktrína uplatňuje v súkromnom práve a ako v práve trestnom.

Všeobecným pravidlom, ktoré je uplatňované $\mathrm{v}$ právnom poriadku každého štátu (má sa na mysli federálneho štátu USA - pozn. autora) je to, ktoré vymedzil Najvyšší súd USA v prípade Grahan a Hoard: kupujúci kúpou korporátnej jednotky alebo jej aktív neprevezme na seba zodpovednost' za túto spoločnost' alebo jej aktíva, ledaže by opačne ustanovil zákon alebo zmluva. Zmyslom je tu to, že ak niekto prevezme inú spoločnost', pôvodná spoločnost' si ponecháva svoju oddelenú právnu identitu; ipso facto to neznamená, že splýva s kupujúcim. ${ }^{17}$ Bez ohl'adu na všeobecné pravidlo o nezodpovednosti právneho nástupcu, súdy tradične rozoznávajú výnimky k uvedenému, a to vtedy, ked’:

- nadobúdatel' výslovne alebo implicitne prevezme na seba zodpovednost';

- obchod je pokusom o podvodné vyhnutie sa vyvodeniu zodpovednosti;

- predmet činnosti nadobúdajúcej spoločnosti je len „obyčajným pokračovaním“ predmetu činnosti predávajúceho;

- obchod znamená de facto fúziu. ${ }^{18}$

Pretransformované do slov kontinentálneho právneho systému: všeobecným pravidlom pre oblast' súkromného práva je, že zodpovednost' zásadne neprechádza na právneho nástupcu právnickej osoby, ak osobitný zákon neustanoví inak.

Práve $\mathrm{v}$ tomto ohlade sa právne dôsledky existencie doktríny o prechode zodpovednosti na právneho nástupcu právnickej osoby vo verejnom práve a v súkromnom práve od seba najviac odlišujú.

Pre verejné právo (trestné právo) totiž platí, že zodpovednost’ prechádza na právneho nástupcu vždy. Ako s dávkou nadnesenia uvádza právna teória, pokial' neuplynie lehota na vyvodenie zodpovednosti, potom trestná zodpovednost' prežije reorganizáciu spoločnosti a všetci právni nástupcovia zdedia trestné poškvrnenie svojho predchodcu. ${ }^{19}$

16 NANDA, V. P. Corporate Criminal Liability in the United States: Is a New Approach Warranted? In: PIETH, M. a R. IVORY. Corporate Criminal Liability: Emergence, Convergence, and Risk. Springer, 2011, s. 65. Dostupné z: https://books.google.sk/books?id=-o2ycT3hWccC \& pg=PR7 \& hl=cs \& source=gbs_selected_pages $\& \mathrm{cad}=3 \#_{\mathrm{v}}=$ onepage $\& \mathrm{q} \& \mathrm{f}=$ false [cit. 16. 10. 2019].

17 FELLMETH, A. X. Cure without Disease: The Emerging Doctrine of Successor Liability in International Trade Regulation. In: The Yale Journal of International Law, 2006, roč. 31, s. 136. Dostupné z: https://digitalcommons.law.yale.edu/cgi/viewcontent.cgi?article=1263 \& context=yjil [cit. 15. 10. 2019].

18 PHILIPS, T. J. The Federal Common Law of Successor Liability and the Foreign Corrupt Practices Act. In: William \& Mary Business Law Review, 2015, roč. 6, s. 102. Dostupné z: https://scholarship.law. wm.edu/cgi/viewcontent.cgi?article $=1083 \&$ context $=$ wmblr [cit. 16. 10. 2019].

19 „Absent the expiry of the statute of limitations, the criminal liabilities of predecessors survive reorganization, and all successors inherit the criminal taint. "DIAMANTIS, M. E. Successor Identity. In: Yale Journal on Regulation, s. 15. Dostupné z: https://ssrn.com/abstract=3131184 [cit. 16. 10. 2019]. 
Podstatou tohto prístupu je, aby si právnická osoba uvedomila, že len v dôsledku reorganizácie, ked’ z pôvodnej právnickej osoby vznikne právnická osoba iná (napríklad v dôsledku splynutia, zlúčenia či rozdelenia ${ }^{20}$ ) nedochádza k zániku zodpovednosti. Zodpovednost' preto nasleduje aj právne kroky spojené so zánikom právnickej osoby bez likvidácie. Ide o nástroj, ktorý má zabránit’ špekulatívnym zánikom právnických osôb.

Tento istý záver možno uviest' aj vo vzt'ahu ku kontinentálnemu právnemu systému, ktorý postupne začal preberat' do národných poriadkov jednotlivých európskych štátov trestnú zodpovednost' právnických osôb, a to vrátane aspektov prechodu zodpovednosti na právneho nástupcu. Povinnost' zaviest' pravú trestnoprávnu zodpovednost' právnických osôb možno vysledovat' v mnohých medzinárodných dokumentoch. Vzhl'adom na ich početnost' odkážem na príslušnú literatúru. ${ }^{21}$

$\mathrm{V}$ súčasnosti koncepty pravej trestnoprávnej zodpovednosti právnických osôb poznáme napríklad v týchto štátoch Európy: Česká republika od roku 2012, ${ }^{22}$ Estónsko od 2002, ${ }^{23}$ Chorvátsko a Srbsko od 2004, ${ }^{24}$ Macedónsko od 2004, ${ }^{25}$ Mad'arsko od 2001, ${ }^{26}$ Slovinsko od 2008, ${ }^{27}$ Slovensko od 2016. ${ }^{28}$ Pol'sko v roku 2018 predstavilo návrh takéhoto zákona. ${ }^{29}$

20 Vo všeobecnosti pozri \ 69 Obchodného zákonníka.

21 Pozri najmä LORKO, J. a M. MEZEI. In: BURDA, E., M. KORDÍK, L. KURILOVSKÁ, T. STRÉMY a kol. Zákon o trestnej zodpovednosti právnických osôb. Komentár. Bratislava: C. H. Beck, 2017, s. 16-18; ZÁHORA, J. In: ZÁHORA, J. a I. ŠIMOVČEK. Zákon o trestnej zodpovednsoti právnických osôb. Komentár. Bratislava: Wolters Kluwer, 2016, s. 15-19 a s. 56-62.

22 ŠÁMAL, P. a kol. Trestni odpovédnost právnických osob. Praha: C. H. Beck, 2018, $992 \mathrm{s.}$

23 GINTER, J. Criminal Liability of Legal Persons in Estonia. Dostupné z: https://www.juridicainternational. eu/public/pdf/ji_2009_1_151.pdf [cit. 24. 10. 2019].

24 MILJAKOVIC, S. D. a V. BOZIC. Criminal Responsibility of Legal Persons in the Legislation of Republic of Serbia and the Republic of Croatia. Dostupné z: https://bib.irb.hr/datoteka/854562.Criminal-responsibility-oflegal-person.pdf [cit. 24. 10. 2019].

25 STOJANOVSKI, V. Criminal Liability of Legal Persons in the Republic of Macedonia. Dostupné z: https:// www.law.muni.cz/sborniky/dp08/files/pdf/trest/stojanowski.pdf [cit. 24. 10. 2019].

26 BERETHLAMI, P. Criminal Liability of Companies. Hungary. Dostupné z: http://www.lexmundi.com/ Document.asp?DocID=3711 [cit. 24. 10. 2019].

27 JAKULIN, V. The Criminal Liability of Legal Persons in the Republic of Slovenia. Dostupné z: https://www. law.muni.cz/sborniky/dp08/files/pdf/trest/jakulin.pdf [cit. 24. 10. 2019].

28 BURDA, E., M. KORDÍK, L. KURILOVSKÁ, T. STRÉMY a kol. Zákon o trestnej zodpovednosti právnických osôb. Komentár. Bratislava: C. H. Beck, 2017, 560 s.

29 CMS LEGAL SERVICES. Poland: New rules for criminal liability of corporate entities. Dostupné z: https:// www.cms-lawnow.com/ealerts/2018/06/poland-new-rules-for-criminal-liability-of-corporate-entities [cit. 24. 10. 2019]. Do pol’ského parlamentu bol návrh toho zákona predložený začiatkom roka 2019 pozri MAGNUSSONLAW.COM 2019 Upcoming Legal Changes New Act of the Accountibility of Collective Entities. Dostupné z: https://www.magnussonlaw.com/publication/2019-02-25/110/2019-upcoming-legal-changes-new-act-of-the-accountability-of-collective-entities [cit. 25. 10. 2019]. 
Pre kontinentálnu Európu je pritom charakteristické, že jej právna úprava dáva (zásadne) odpoved' na tieto tri aspekty zodpovednosti právnických osôb:

a) výber právnických osôb, ktoré sú trestne zodpovedné,

b) typológia trestných činov, ktoré právnická osoba je spôsobilá spáchat',

c) kritériá pričítatel’nosti zodpovednosti právnickej osobe. ${ }^{30}$

Na základe uvedeného rozboru preto možno konštatovat', že síce právna zodpovednost' právnickej osoby je konceptom, ktorý by tu v rámci kontinentálnej Európy bol aj bez ohl'adu na angloamerický právny systém, ${ }^{31}$ na strane druhej treba povedat', že kontinentálny právny systém $\mathrm{v}$ tejto oblasti mnohé prevzal práve $\mathrm{z}$ toho angloamerického, a to najmä v ohl'ade prechodu zodpovednosti na právneho nástupcu právnickej osoby.

Domnievam sa, že v dôsledku zbližovania trestného práva a správneho práva v oblasti správneho trestania možno očakávat', že trestné právo a jeho štandardy nájdu uplatnenie aj v rámci správneho práva, a preto sa treba venovat’ systematickej analýze prechodu právnej zodpovednosti právnickej osoby aj v rámci správneho práva. A práve tu opät' možno vidiet' ako významný inšpiračný zdroj poznanie vedy angloamerického právneho systému, ktoré tento prechod postupne rozvinula až do dnešnej podoby.

Analýza je však nevyhnutná aj z toho dôvodu, že tiež nám môže dat’ dve rozličné odpovede na otázku, či aj v oblasti správneho práva je nevyhnutné, aby dochádzalo k prechodu právnej zodpovednosti na právneho nástupcu. Táto odpoved' môže byt' pozitívna - v takom prípade treba analyzovat' podmienky, za ktorých táto zodpovednost' prejde na právneho nástupcu a v akom rozsahu. Táto odpoved' však môže byt' aj negatívna - v takom prípade ide o odpoved', podl'a ktorej prechod zodpovednosti právnickej osoby v správnom práve je nadbytočný inštitút a jeho zavedenie nemožno odporučit'.

$\mathrm{Na}$ úplnost' ilustrácie toho, že právna zodpovednost' právneho nástupcu právnickej osoby je celosvetovým fenoménom, si dovolím si uviest', že aj islamský právny systém (resp. jeho čast') tiež akceptuje tieto myšlienky. Možno sa dočítat', že tento právny systém prevzal mnohé z myšlienok kontinentálneho právneho systému, pričom aj v arabskom svete je diskutovanou otázka zodpovednosti právnickej osoby. Niektoré arabské krajiny celkom prevzali koncept trestnoprávnej zodpovednosti a nerozlišujú medzi súkromnými a verejnými právnickými osobami, ide napríklad o Sýriu a Libanon. Na druhej strane niektoré arabské krajiny akceptujú aplikáciu tohto princípu len na súkromné právnické osoby a nie na verejné ako napríklad Spojené arabské emiráty, Jordánsko, Irak a Bahrajn.

30 Pozri DE MAGLIE, C. Models of Corporate Crimal Liability in Comparative Law. In: Washington University Global Studies Law Review, 2005, č. 4, s. 550. Dostupné z: https://openscholarship.wustl.edu/ cgi/viewcontent.cgi?article $=1213 \&$ context $=$ law_globalstudies [cit. 17. 10. 2019].

31 Osobitne to platí v prípade trestania právnických osôb v správnom práve; napríklad Nemecko dodnes nepozná pravú trestnoprávnu zodpovednost' týchto osôb. Rovnako tak pozri historické korene správneho trestania právnických osôb; PRÁŠKOVÁ, H. Správní delikty právnických osob. In: Acta Facultatis Carolinae Iuridica, 1992, č. 4-5, s. 4-9; PRÁŠKOVÁ, H. Základy odpovédnosti za správní delikety. Praha: C. H. Beck, 2013, s. 157-161. 
Tretia skupina arabských krajín odmietla uznat' právnu zodpovednost’ právnických osôb s niektorými výnimkami ohladom finančnej a ekonomickej trestnej činnosti ako napríklad Alžírsko, Egypt, Líbya a Kuvajt. ${ }^{32} \mathrm{~V}$ krajinách Južnej Ameriky táto téma rezonuje najmä vo vzt’ahu k trestným činom korupcie. Brazília zaviedla trestnoprávnu zodpovednost' právnických osôb v tejto oblasti v roku 2013, Chile v roku 2013, Kolumbia v roku 2016, Peru v roku 2016, Venezuela v roku 2016 a Argentína v marci 2018. ${ }^{33}$

Zosumarizovaním poznatkov z prvej časti tohto článku preto možno uviest’ tieto čiastkové závery:

a) pôvodné myšlienky vôbec vyvodzovania zodpovednosti voči právnickým osobám nachádzame v angloamerickom právnom systéme;

b) súdy v angloamerickom právnom systéme využili na vytvorenie možnosti sankcionovat' právnické osoby pôvodne súkromnoprávnu doktrínu respondeat superior,

c) súdy túto doktrínu aplikujú v odlišnej podobe oproti súkromnoprávnym vzt’ahom, a to tak, že zodpovednost’ prežije aj zánik právnickej osoby v dôsledku jej splynutia, zlúčenia alebo rozdelenia;

d) z angloamerickej právnej kultúry sa vyvodzovanie zodpovednosti voči právnickým osobám a prechod zodpovednosti na ich právneho nástupcu dostalo aj do kontinentálneho právneho systému;

e) v kontinentálnom právnom systéme o zodpovednosti právnických osôb a prechode ich zodpovednosti hovoria mnohé medzinárodné zmluvy z oblasti trestného práva, pričom záväzky z nich plynúce akceptuje čoraz väčšie množstvo právnych poriadkov jednotlivých štátov Európy;

f) vzhl’adom na približovanie sa trestného práva a správneho práva v oblasti správneho trestania a zachovania rovnakých štandardov trestania voči osobám fyzickým, ako aj právnickým, sú aj v oblasti správneho práva na mieste otázky spojené s prechodom správnoprávnej zodpovednosti na právneho nástupcu právnickej osoby.

\section{Prechod administratívnoprávnej zodpovednosti na právneho nástupcu právnickej osoby v ostatných krajinách V4 $\mathrm{s}$ dôrazom na českú právnu úpravu}

Prechod administratívnoprávnej zodpovednosti na právneho nástupcu právnickej osoby je dnes aktuálnou otázkou aj v oblasti správneho práva. Táto aktuálnost’ vyplýva jednak

32 FAQIR, R. S. A. The Criminal Liability of Parent Corporations for Acts of Its Subsidiaries under Criminal Law in Jordan: A Comparative Study. In: Beijing Law Review, 2016, č. 7, s. 223-224. Dostupné z: https:// www.researchgate.net/publication/307612375_The_Criminal_Liability_of_Parent_Corporations_for_ Acts_of_Its_Subsidiaries_under_Criminal_Law_in_Jordan_A_Comparative_Study [cit. 16. 10. 2019].

33 MAYER \& BROWN. Argentine Law that Establishes Corporate Criminal and Administrative Liability for Corruption Enters Into Force March 2018. Dostupné z: https://www.mayerbrown.com/argentine-law-that-establishes-corporate-criminal-and-administrative-liability-for-corruption-enters-into-force-march-2018-02-01-2018/ [cit. 28. 10. 2019]. 
zo skutočnosti, že aj právna prax pocit'uje deficit v tejto oblasti, ${ }^{34}$ ako aj z faktu existencie právnej úpravy prechodu trestnoprávnej zodpovednosti na právneho nástupcu. Uvedená druhá skutočnost' rezultuje do otázok o možnom analogickom využití tohto inštitútu aj v oblasti správneho práva.

Pred tým, než sa dostanem k právnej úprave de lege lata, treba povedat', že dôraz na právnu úpravu v Českej republike som si zvolil z dôvodu, že ich právna úprava už v súčasnosti priamo upravuje prechod administratívnoprávnej zodpovednosti na právneho nástupcu právnickej osoby. Dôvod, pre ktorý sa v takejto miere nevenujem ostatným krajinám V4, ku ktorým všeobecne máme najbližšie historické väzby, je ten, že v oboch štátoch táto špecifická právna úprava neexistuje. ${ }^{35}$

V Mad'arsku platí, že prechod zodpovednosti na právneho nástupcu právnickej osoby nie je legislatívne upravený. V rámci rozhovorov s mad’arskými kolegami vyplynulo, že prechod zodpovednosti na právneho nástupcu právnickej osoby by bol možný riešit' prostredníctvom analogického využitia civilných predpisov.

Osobne nie som presvedčený o vhodnosti tohto prístupu, pretože v konečnom dôsledku by sa jeho aplikáciou rozšírila možnost' sankcionovat' subjekt deliktu, čo je v rozpore so zákazom analógie na prospech. Dovolím si tvrdit', že tento postup by bol v rozpore s čl. 6 Dohovoru.

Vo vzt'ahu k Pol’sku treba uviest', že ich právne predpisy taktiež všeobecne neupravujú prechod administratívnoprávnej zodpovednosti na právneho nástupcu právnickej osoby. Pol'ská právna úprava, na rozdiel od mad'arskej, však môže využit' niektoré z ustanovení Správneho poriadku ${ }^{36}$ a aj predpisy civilného práva.

Podl’a čl. 30 \ 4 pol’ského správneho poriadku v prípadoch prevoditel’ných alebo zdeditel'ných práv, ak dôjde $\mathrm{k}$ predaju práva alebo smrti strany počas konania, vstupujú do konania jej právni nástupcovia. Problémom tu je, že ustanovenie sa týka prevodu práv a nie povinností a rovnako tak aj jeho celkové znenie, ktoré skôr smeruje k účastníkovi konania ako fyzickej osobe (porovnaj formuláciu „smrt’ strany“).

Z daného dôvodu sa možno pozriet’ aj do všeobecnejšieho ustanovenia. Podl’a čl. 30 \ 1 pol'ského správneho poriadku pokial' osobitný právny predpis neustanoví inak, právna spôsobilost' sa bude posudzovat' podl'a predpisov súkromného práva. Súkromnoprávne predpisy však zásadne upravujú len zmenu právnej formy spoločnosti - pozri čl. 553 \ 1

34 Pozri d'alej v texte.

35 Len pre zaujímavost' uvediem, že napríklad ukrajinský kódex o správnych deliktoch všeobecne síce upravuje zodpovednost' právnickej osoby za správny delikt, ale nie prechod jej zodpovednosti na právneho nástupcu, avšak napríklad ruský federálny zákon o správnych deliktoch v článku 2.10 bodoch 3 až 6 výslovne upravuje zodpovednost' právneho nástupcu v prípadoch splynutia, zlúčenia či rozdelenia právnickej osoby.

36 Pol'skú verziu pol’ského správneho poriadku pozri z: http://prawo.sejm.gov.pl/isap.nsf/download.xsp/ WDU19600300168/U/D19600168Lj.pdf [cit. 23. 10. 2019]. 
pol’ského obchodného zákonníka. ${ }^{37}$ Možno konštatovat', že táto úprava je obdobná ako v prípade slovenskej právnej úpravy, ${ }^{38}$ a teda nedochádza tu k zániku spoločnosti ako takej.

Ani pol'ská právna úprava tak zásadne neupravuje priamo právnu zodpovednost’ právneho nástupcu právnickej osoby v oblasti správneho práva.

Z krajín V4 sa preto presunieme k právnej úprave v Českej republike, ktorá ako jediná de lege lata upravuje administratívnoprávnu zodpovednost' právneho nástupcu právnickej osoby. Všeobecná právna úprava sa nachádza v českom zákone o priestupkoch ${ }^{39} \mathrm{v} \ 33$. Predmetné ustanovenie nadväzuje na \29 písm. c) českého zákona o priestupkoch, podl'a ktorého zánik právnickej osoby sa považuje za zánik zodpovednosti za priestupok, pokial' právnická osoba nemá právneho nástupcu. V \33 sa potom v dvoch odsekoch upravuje prechod právnej zodpovednosti na právneho nástupcu. Podl’a odseku 1 zodpovednost' právnickej osoby za priestupok prechádza na jej právneho nástupcu. Podl'a odseku 2 ak má právnická osoba viac právnych nástupcov, zodpovedá za priestupok každý z nich tak, akoby priestupok spáchal sám. Na toto ustanovenie potom ešte nadväzujú d'alšie ustanovenia, ktoré upravujú určenie druhu a výmery správneho trestu, ${ }^{40}$ odloženie veci, ${ }^{41}$ výrokovú čast' rozhodnutia o priestupku, ${ }^{42}$ či prechod úhrady pokuty na právneho nástupcu. ${ }^{43}$

Dôvod zavedenia tejto právnej úpravy vyjadruje dôvodová správa k českému zákonu o priestupkoch takto: ciel’om návrhu je zabránit', aby právnická osoba, ktorá spácha

37 Pol’skú verziu pol’ského obchodného zákonníka pozri z: http://prawo.sejm.gov.pl/isap.nsf/download. xsp/WDU20000941037/U/D20001037Lj.pdf [cit. 23. 10. 2019].

38 \69 b Obchodného zákonníka - zmena právnej formy spoločnosti, kde podl’a ods. 1 tohto ustanovenia zmenou právnej formy spoločnost’ ako právnická osoba nezaniká.

39 Zákon č. 250/2016 Sb., o odpovědnosti za přestupky a řízení o nich (d’alej len „český zákon priestupkoch“).

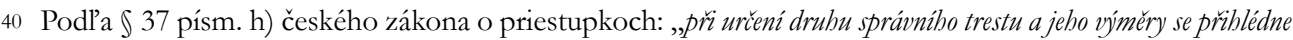
zejména u právního nástupce ke tomu, v jakém rozsabu na nèj prèsly výnosy, užittey a jiné výhody ze spáchaného prèstupku,

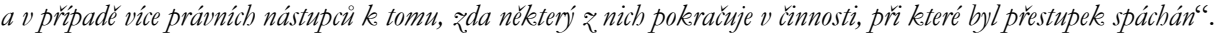

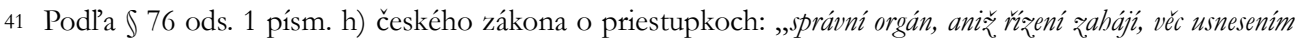

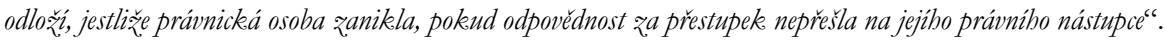

42 Podl'a $\int 93$ ods. 2 a ods. 3 písm. h) českého zákona o priestupkoch: ,ve výrokové části roz̧odnutí o prèstupku, kterým je obvinèný užnán vinným jako pránin nástupce, se kromè nálě̌itostí podle odstavce 1 wedou a) identifikačni údaje osoby, která skutek spáchala, a b) údaj o tom, že osoba, které je rozhodnutím ukládán správni trest, je právním nástupcem právnické osoby, která se dopustila prèstupku, poprĭpadě osobou, která pokračuje v podnikatelské rinnosti zemrèlé podnikajicí fyzickeé osoby, keterá se dopustila prèstupken“. „Ve výrokové cáasti rozbodnuti o scbválení dohody o narovnání se kromè nálę̌itosti podle správníbo rádu uvede údaj o tom, ře osoba, keterá uzavréla dobodu o narovnání, je právním nástupcem právnické osoby, která se dopustila prèstupku, poprípadè osobou, která pokračuje v podnikatelské cínnosti zemrelé podnikajici fyzické osoby, která se dopustila prestupkeu“.

43 Podl’a \102 českého zákona o priestupkoch: ,pokud po nabytí prámi moci rožbodnutí o préstupku, kterým byla pachateli, jen ̌̌je právnickou osobou, ulo ̌̌ena pokuta, došlo k zániku pachatele pred uplynutím lhrity pro nař̌zení exekuce, aniž byla pokuta ubrażena, a pachatel má práviíbo nástupce, pak povinnost ubradit pokutu préchází na tohoto právníbo nástupce. Má-li pachatel vice prámnich nástupcui, za ubrazeni pokuty odpovídaji právni nástupci společně a nerozdilne“. 
priestupok, unikla zodpovednosti napríklad tým, že účelovo dobrovol’ne zanikne a spôsobí tak prechod práv a povinností na nový subjekt, svojho právneho nástupcu, ktorý by inak nebolo možné za priestupok postihnút'. Zakotvením prechodu zodpovednosti právnickej osoby na jej právneho nástupcu má byt' st’ažené získanie prospechu právnickou osobou, ktorá by sa po spáchaní priestupku snažila marit’ účel uloženia správneho trestu (pokuty) naznačeným spôsobom či iným spôsobom s podobnými dôsledkami. ${ }^{44}$

Zodpovednost' za priestupok teda zaniká len vtedy, ak právnická osoba nemá právneho nástupcu. ${ }^{45}$

V prípade zániku právnickej osoby s právnym nástupcom dochádza k prechodu zodpovednosti za priestupok na právneho nástupcu - každý z právnych nástupcov potom zodpovedá za priestupok, akoby ho spáchal sám [miera výhod získaných zo spáchaného priestupku sa zohl’adní pri ukladaní trestu, pozri \37 písm. h) zákona]. Ak dôjde k zániku právnickej osoby až po nadobudnutí právoplatnosti rozhodnutia o priestupku, ktorým bola právnickej osobe uložená pokuta, prechádza na právneho nástupcu povinnost' uhradit' pokutu (pozri \102 zákona). ${ }^{46}$ Prechod iných správnych trestov ako pokuty možný nie je; takáto právna regulácia by sa totiž podl’a dôvodovej správy k českému zákonu o priestupkoch zdala ako neefektívna. ${ }^{47}$

Česká odborná literatúra $\mathrm{k}$ zvolenému zákonnému riešeniu zaujala zmiešané názory. $\mathrm{Na}$ jednej strane víta túto právnu úpravu, ale na strane druhej poukazuje aj na viaceré nezodpovedané otázky. Napríklad sa uvádza, že z textu zákona nevyplýva, či prechod je možný len v prípade univerzálnej sukcesie alebo aj singulárnej, ${ }^{48}$ prípadne či môže dôjst' k prechodu zodpovednosti aj na osobu fyzickú. ${ }^{49}$

Ďalej považujem za dôležité upozornit’, že zo znenia textu českého zákona o priestupkoch možno odvodit', že k prechodu zodpovednosti dochádza objektívne. To bude mat' za následok, že k prechodu zodpovednosti dôjde aj v prípade, ked' právny nástupca

44 Dôvodová správa ke českému zákonu o priestupkoch, s. 164-165. Dostupné z: https://www.psp.cz/sqw/text/ orig2.sqw?idd=115252 [cit. 23. 10. 2019].

45 MATES, P. In: MATES, P. a kol. Základy správního práva trestního. Praha: C. H. Beck, 2017, s. 79.

46 Průvodce zákonem č. 250/2016 Sb., o odpovědnosti za přestupky a řízení o nich. Ministerstvo vnitra ČR [online]. S. 29 [cit. 23. 10. 2019]. Dostupné z: http://www.mvcr.cz/soubor/pruvodce-novou-upravou-prestupkoveho-prava.aspx

47 Dôvodová správa ke českému zákonu o priestupkoch, s. 166. Dostupné z: https://www.psp.cz/sqw/text/orig2. sqw?idd=115252 [cit. 23. 10. 2019].

48 Závery právnej teórie sú také, že sa prikláňa k možnosti prechodu len v prípade univerzálnej sukcesie; PRÁŠKKOVÁ, H. Nové prestupkové právo. Praha: Leges, 2017, s. 192; VIČAROVÁ-HEFNEROVÁ, H. In: FRUMAROVÁ, K. a kol. Správni trestání. Praha: Leges, 2017, s. 74.

$49 \mathrm{~V}$ tomto prípade nachádzame $\mathrm{v}$ literatúre záver, že prechod na nepodnikajúcu fyzickú osobu by nemal byt' možný, zatial' čo na podnikajúcu to možné zrejme bude; GRYGAR, T. In: FRUMAROVÁ, K. a kol. Správni trestání. Praha: Leges, 2017, s. 56. 
nevedel (či dokonca ani nemohol vediet’), že pôvodná právnická osoba spáchala priestupok. ${ }^{50}$

Z procesnoprávneho hl'adiska treba vyzdvihnút' právny inštitút zákazu zrušenia, zániku a premeny právnickej osoby rozhodnutím správneho orgánu podl’a $\int 88$ českého zákona o priestupkoch. ${ }^{51}$

Slovenská právna úprava ${ }^{52}$ de lege lata prechod administratívnoprávnej zodpovednosti na právneho nástupcu právnickej osoby v súčasnosti nepozná. Na strane druhej však právna úprava pozná prechod trestnoprávnej zodpovednosti na právneho nástupcu právnickej osoby, a to konkrétne v $\int 7$ TZPO. ${ }^{53}$

Záverom tejto state preto možno skonštatovat', že

a) v krajinách V4 je nad'alej prechod administratívnoprávnej zodpovednosti právnickej osoby na právneho nástupcu $\mathrm{v}$ istom zmysle „tabu“,

b) ponechat' právnu prax na odvodení právnej zodpovednosti právneho nástupcu právnickej osoby na predpisy súkromného práva nezodpovedá požiadavkám práva na spravodlivý proces podl'a čl. 6 Dohovoru,

c) z krajín V4 v zodpovedajúcej kvalite má túto problematiku riešenú de lege lata len Česká republika,

d) z dôvodu jednotnosti právneho poriadku, kde trestnoprávna zodpovednost' prechádza na právneho nástupcu, by bolo vhodné, aby túto problematiku upravili aj predpisy správneho práva.

\section{Súčasná právna úprava prechodu administratívnoprávnej zodpovednosti na právneho nástupcu právnickej osoby na Slovensku}

Zánik právnickej osoby sa v literatúre prirad’uje k dôvodom zániku trestnosti právnickej osoby, pričom sa dodáva, že ide o najkontroverznejší z týchto dôvodov. ${ }^{54}$ Uvedené súvisí s jednotlivými znakmi skutkovej podstaty, kde ak čo i len jeden chýba, nemôže dôjst' k vyvodeniu zodpovednosti za spáchaný protiprávny čin. Zánik právnickej osoby súvisí so zánikom subjektu správneho deliktu. Právnická osoba nie je nositel’om práva na život a ak ukončí svoju existenciu, nedochádza k žiadnej ujme na jej právach; osoby, ktoré vytvorili právnickú osobu, môžu založit' právnickú osobu novú, a to aj s rovnakým predmetom činnosti (podnikania). V prípade právnických osôb takéto tendenčné správanie nemožno vylúčit’.

50 GRYGAR, T. In: FRUMAROVÁ, K. a kol. Správní trestání. Praha: Leges, 2017, s. 56.

51 K tomu pozri VETEŠNÍK, P. In: MATES, P. a kol. Základy spráuního práva trestního. Praha: C. H. Beck, 2017, s. 161-163.

52 Pozri bližšie najmä v d’alšom texte.

53 Zákon č. 91/2016 Z.z. o trestnej zodpovednosti právnických osôb (d’alej len „TZPO“).

54 HORVAT, M. Administratínoprávna zodpovednost’právnickéch osôb. Bratislava: Wolters Kluwer, 2017, s. 114. 
Dôležitost' tejto problematiky podčiarkuje aj TZPO, ktorý ju osobitne rieši v \ 7. Podl'a dôvodovej správy k TZPO otázku prechodu trestnej zodpovednosti právnických osôb je nevyhnutné výslovne upravit' v návrhu zákona, v opačnom prípade by zrušenie právnickej osoby s právnym nástupcom znamenal jednoduchý spôsob, ako sa trestnej zodpovednosti vyhnút'. Takáto právna úprava nie je ojedinelá a možno ju považovat' za štandard $\mathrm{v}$ rámci právnych úprav trestnej zodpovednosti právnických osôb. ${ }^{55}$

TZPO zakotvuje základné pravidlo, podl'a ktorého trestnoprávna zodpovednost' právnickej osoby, ktorá bola zrušená, prechádza na všetkých jej právnych nástupcov, pričom prechod trestnej zodpovednosti na jej právnych nástupcov sa týka aj uložených trestov. Trestnoprávna teória preto v tejto súvislosti hovorí o novej zásade - zásade trestnej zodpovednosti právneho nástupcu právnickej osoby. ${ }^{56}$

Ako d’alej pripomína právna teória, tak ustanovenie $\int 7$ ods. 1 TZPO upravuje prechod trestnej zodpovednosti právnickej osoby na jej právnych nástupcov, avšak títo právni nástupcovia musia byt' právnické osoby. Prechod trestnej zodpovednosti na fyzickú osobu je výslovne vylúčený. ${ }^{57}$ Z uvedeného vyplýva, že na rozdiel od trestnej zodpovednosti fyzických osôb, pri ktorých trestná zodpovednost', okrem iných okolností, zaniká aj smrt'ou páchatel’a, pri právnickej osobe nemá zánik právnickej osoby vždy za následok zánik trestnej zodpovednosti tejto právnickej osoby. ${ }^{58}$

TZPO vychádza z tzv. širokej koncepcie právneho nástupníctva trestnej zodpovednosti právnických osôb. Jej podstata spočíva $\mathrm{v}$ tom, že trestná zodpovednost' právnických osôb prechádza na všetkých právnych nástupcov právnickej osoby. (...) [S tým, že] pôvodná právnická osoba, ktorá bola trestne zodpovedná, bola zrušená. Momentom prechodu trestnej zodpovednosti je teda vznik relevantného právneho nástupníctva, pričom v tomto čase už musí byt' právnická osoba zrušená. ${ }^{99} \mathrm{~K}$ prechodu trestnej zodpovednosti právnickej osoby dochádza v zmysle $\int 7$ TZPO objektívne, bez ohl'adu na to, či právnická osoba ako právny nástupca vedela (resp. mohla vediet’), že sa pôvodná právnická osoba dopustila trestného činu. ${ }^{60}$

55 Dôvodová správa k TZPO, s. 20. Dostupné z: https://www.nrsr.sk/web/Dynamic/DocumentPreview. aspx?DocID=417982 [cit. 26. 10. 2019].

56 TURAYOVÁ, Y., L. TOBIÁŠOVÁ, J. ČENTÉŠ a kol. Trestná zodpovednost právnických osôb. Vybrané aspek.ty trestnej zodpovednosti právnickéch osôb v SR. Bratislava: Wolters Kluwer, 2016, s. 60.

57 BURDA, E. In: BURDA, E., M. KORDÍK, L. KURILOVSKÁ, T. STRÉMY a kol. Zákon o trestnej zodpovednosti právnickéch osôb. Komentár. Bratislava: C. H. Beck, 2017, s. 158.

58 ZÁHORA, J. In: ZÁHORA, J. a I. ŠIMOVČEK. Zákon o trestnej zodpovednosti práunických osôb. Komentár. Bratislava: Wolters Kluwer, 2016, s. 124.

59 BURDA, E. In: BURDA, E., M. KORDÍK, L. KURILOVSKÁ, T. STRÉMY a kol. Zákon o trestnej zodpovednosti právnických osôb. Komentár. Bratislava: C. H. Beck, 2017, s. 160.

60 ZÁHORA, J. In: ZÁHORA, J. a I. ŠIMOVČEK. Zákon o trestnej zodpovednosti právnických osôb. Komentár. Bratislava: Wolters Kluwer, 2016, s. 125. 
Zásada administratívnoprávnej zodpovednosti právneho nástupcu právnickej osoby v právnych predpisoch Slovenskej republiky nie je upravená. V nasledujúcom texte sa preto zameriam na možnosti prechodu právnej zodpovednosti na nástupcu právnickej osoby, analýzu súdnej judikatúry k tejto problematike a v poslednej časti príspevku aj na návrhy de lege ferenda. ${ }^{61}$

Súčasná právna úprava správneho trestania de lege lata neupravuje prechod zodpovednosti na právneho nástupcu, avšak je zaujímavé, že v judikatúre sa s týmto právnym inštitútom stretnút' možno, a to dokonca nielen v jednom rozhodnutí, ale vo viacerých. $\mathrm{Na}$ účely tohto článku pritom vychádzam z prípadu, kde sa slovenské správne súdy po prvýkrát zaoberali prechodom administratívnoprávnej zodpovednosti na právneho nástupcu právnickej osoby.

$\mathrm{V}$ posudzovanom prípade $^{62}$ sa správne súdy zaoberali správnou žalobou Železničnej spoločnosti Cargo Slovakia, a. s. (žalobca) podanou voči rozhodnutiu Protimonopolného úradu Slovenskej republiky (žalovaný). Žalovaný v správnom konaní dospel k záveru, že Železničná spoločnost', a. s., ako právny predchodca žalobcu, ${ }^{63}$ sa dopustila protisút'ažného konania, a to zneužitím svojho dominantného postavenia na trhu, ked' dohodla poskytovanie provízie pri poskytovaní služieb železničnej nákladnej dopravy hromadných substrátov pre vel'koodberatelov na stredných a dlhých tratiach na území Slovenskej republiky. Za toto protiprávne konanie udelila žalobcovi pokutu vo výške 37000000 Sk. ${ }^{64}$ Pokutu z dôvodu neexistencie Železničnej spoločnosti, a. s., udelil žalovaný právnemu a ekonomickému nástupcovi tejto spoločnosti, t. j. žalobcovi.

Vo vzt'ahu k zániku právnickej osoby ako dôvodu zániku zodpovednosti treba povedat', že žalobca v správnej žalobe namietal práve tú skutočnost’, že je síce právnym nástupcom Železničnej spoločnosti, a. s., ale zároveň žiadny právny predpis neupravuje prechod zodpovednosti za správny delikt právnickej osoby. Napriek tomu žalovaný sankcionuje žalobcu po právnom predchodcovi. Argumentuje, že pokial’ bol žalobca prešetrovaný za protiprávne konanie zaniknutej spoločnosti, mala byt' prešetrovaná aj Železničná spoločnost' Slovensko, a. s., pretože tiež ide o právneho nástupcu po Železničnej spoločnosti, a. s., ktorá rovnako prebrala všetky práva a záväzky po právnom predchodcovi;

61 Obdobnú analýzu pre Českú republiku pozri PRÁŠKOVÁ, H. Základy odpovédnosti za správni delikety. Praha: C. H. Beck, 2013, s. 380-384.

62 Skutkové a právne zhodnotenie vychádza, okrem iného, najmä z nasledovných dokumentov: rozhodnutie Protimonopolného úradu Slovenskej republiky z 12. mája 2006, č. 2006/DZ/R/2/055, rozsudok Krajského súdu v Bratislave zo 7. novembra 2007, sp. zn. 2 S 258/06-69, a rozsudok Najvyššieho súdu Slovenskej republiky zo 14. augusta 2008, sp. zn. 8Sžhpu/1/2008. Všetko dostupné z: http://www.antimon.gov.sk/zeleznicna-spolocnost-cargo-slovakia-as-bratislava/

63 Zo štátneho podniku Železnice Slovenskej republiky sa v r. 2002 oddelila Železničná spoločnost', a. s., ktorá sa v r. 2005 rozdelila na podniky Železničná spoločnost' Slovensko, a. s. (osobná doprava), a Železničná spoločnost' Cargo Slovakia, a. s. (nákladná doprava). Železnice Slovenskej republiky, a. s., zabezpečujú prevádzkovanie dráhy, údržbu a modernizáciu železničných tratí.

64 Približne $1228175 €$. 
ekonomické nástupníctvo je v tomto prípade bezvýznamné a nepodstatné. Tým, že žalovaný rozhodoval o tom, že určitý podnikatel' porušil zákon v čase, ked' neexistoval, a teda nemohol konat' protiprávne, vydal nezákonné rozhodnutie, ktoré treba zrušit'.

Žalovaný pri svojom rozhodovaní vychádzal z testu ekonomickej kontinuity (nástupníctva) a case-law (vtedajšieho) Európskeho súdneho dvora a Súdu prvého stupňa. Považoval za preukázané, že žalobca je ekonomickým nástupcom zaniknutej spoločnosti, ked’že na žalobcu z nej prešli materiálne a l'udské zdroje v rámci železničnej nákladnej dopravy a pokračuje v tejto oblasti v rovnakých ekonomických aktivitách. Podstatný tu je vstup do ekonomických aktivít podnikatel'a, t. j. nástupníctvo v ekonomickom zmysle, nie $\mathrm{v}$ právnom zmysle, pričom tento výklad zodpovedá aj ciel’om ochrany hospodárskej sút'aže tak, aby konanie, ktoré negatívne ovplyvnilo fungovanie trhu a malo byt' potrestané, neostalo bez sankcie len z dôvodu organizačných, či štrukturálnych zmien na strane podnikatel’ov. Preto je ekonomickým nástupcom len žalobca a nie aj Železničná spoločnost' Slovensko, a. s.

Treba povedat', že oba tieto názorové prúdy majú svojich zástancov. ${ }^{65} \mathrm{~V}$ predmetnej veci pri jej posúdení možno vychádzat' aj zo spomínanej judikatúry európskych súdov. O teste ekonomickej kontinuity sa hovorí už od prípadu Suicker Unie vs. Európska Komisia. ${ }^{66}$ Podstata prípadu spočívala v tom, že štyri cukrárske družstvá sa dopustili rôznych protisút’ažných deliktov a boli následne zrušené bez likvidácie a ich majetok, práva a záväzky boli prevedené na novozaloženú spoločnost' Suiker Unie. Tá tvrdila, že nemôže niest' zodpovednost' za pôvodný koordinačný orgán cukrárskych družstiev, pretože tento orgán nemal žiadny majetok alebo goodwill, ktorý by mohol byt' (alebo bol) prenesený na novú spoločnost'. Európsky súdny dvor konštatoval, že nová cukrárska spoločnost' prevzala všetky práva a záväzky pôvodných štyroch družstiev a že nová spoločnost' sa kryla s tým istým podnikom, mala rovnaké sídlo a správala sa na trhu úplne rovnako ako koordinačný orgán. Pretože Európsky súdny dvor konštatoval evidentnú identitu hlavných rysov aktivity nového podniku a jeho predchodcu, prisúdil celú zodpovednost' za správanie bývalého koordinačného orgánu družstiev jeho ekonomickému nástupcovi - Suiker Unie. ${ }^{67}$

$65 \mathrm{~K}$ argumentom o nemožnosti právneho nástupníctva pozri napríklad ŠEMORA, V. K procesnímu nástupnictví ve správním řízení, zejména s ohledem na řízení o soutěžních deliktech. In: Právní roz̧bledy, 2007, roč. 15, č. 5, s. 175-180; a KINDL, J. Do třetice k procesnímu nástupnictví zaniklých právnických osob v soutěžních věcech. In: Právní roz̧bledy, 2007, roč. 15, č. 21, s. 789-792; K argumentom o nevyhnutnosti nástupníctva pozri NERUDA, R. a L. GACHOVÁ. Ještě k procesnímu nástupnictví zaniklých právnických osob v soutěžních věcech. In: Právní roz̧hledy, 2007, roč. 15, č. 15, s. 561-562; a najmä BEJČEK, J. Veřejný zájem, procesní nástupnictví a spravedlnost aneb „fiat lex (in stricto nonsensu), pereat iustitia?““. In: Právní roz̧bledy, 2008, roč. 16, č. 12, s. 441-447.

$66 \mathrm{~K}$ d'alšiemu európskemu case-law (prípad Ancic a prípad NMH Stablwerke) pozri HAMULÁKOVÁ, Z. Správne delikety právnických osôb - vybrané institututy a problémy. Bratislava: Wolters Kluwer, 2018, s. 263-266.

67 BEJČEK, J. Veřejný zájem, procesní nástupnictví a spravedlnost aneb „fiat lex (in stricto nonsensu), pereat iustitia?“. In: Právní roz̧hledy, 2008, roč. 16, č. 12, s. 444. Pozri aj iné prípady, ktoré boli riešené európskymi súdnymi inštitúciami spomínanými v tomto článku. 
Správne súdy v prípade Protimonopolného úradu Slovenskej republiky dali za pravdu tomuto orgánu, pričom sa priklonili k výkladu o ekonomickom nástupníctve, a teda k judikatórnej línii európskych súdov. Správne súdy však v prípade využili svoje moderačné oprávnenie, ked’ znížili sankciu na 5000000 Sk. ${ }^{68}$

Okrem spomínaného prípadu sa prechodu administratívnoprávnej zodpovednosti venujú správne súdy aj v iných prípadoch. Príkladom môže byt' prípad vedený Najvyšším súdom Slovenskej republiky pod sp. zn. 1Sžhpu/2/2008 z 26. októbra 2010, kde Najvyšší súd Slovenskej republiky v odôvodnení svojho rozsudku uviedol, že z ustálenej judikatúry možno vyvodit', že protisút'ažné správanie jednej spoločnosti môže byt pripísané inej, ak sú splnené dve podmienky: nová spoločnost’ pokračuje v aktivitách predchádzajúcej spoločnosti - subjektu, ktorý sa dopustil porušenia, t. j. existuje kontinuita ekonomických činností a druhá, že pôvodný subjekt zanikol. Ciel’om je zabezpečit', aby správanie, ktoré by malo byt' potrestané, nezostalo nepotrestané a neboli zmarené ciele ochrany sút'aže z dôvodu určitých zmien z podnikatel'ov. V prvom rade je teda sankcionovaný vždy porušovatel’ a v prípade jeho zániku jeho nástupca, ktorý prevzal jeho materiálne a l'udské zdroje v rámci podnikania a ktorý pokračuje v jeho ekonomickej aktivite.

$\mathrm{Na}$ tento rozsudok nadväzuje na nižšej úrovni napríklad aj rozsudok Krajského súdu v Bratislave z 15. októbra 2013, sp. zn. 5S/164/2012. Krajský súd v tomto prípade posudzoval prechod právnej zodpovednosti na Rozhlas a televíziu Slovensko z pôvodných právnických osôb - Slovenská televízia a Slovenský rozhlas.

Obdobnú vec (t. j. prechod zodpovednosti vo veci Rozhlasu a televízie Slovenska) posudzoval Najvyšší súd Slovenskej republiky aj vo veci vedenej pod sp. zn. 4Š̌/10/2012 z 18. septembra 2012. Aj v tomto prípade súd odkázal na rozsudok z 26. októbra 2010, sp. zn. 1Sžhpu/2/2008.

Tieto všetky prípady sú však vel’mi zaujímavé aj z toho dôvodu, že rozsudok Najvyššieho súdu Slovenskej republiky z 26. októbra 2010, sp. zn. 1Sžhpu/2/2008, bol zrušený Ústavným súdom Slovenskej republiky. Uvedené sa konštatuje v náleze Ústavného súdu Slovenskej republiky zo 14. júna 2011, sp. zn. III. ÚS 170/2011. Možno si teda povšimnút', že správne súdy odkazujú vo svojich záveroch na zrušené rozhodnutie Najvyššieho súdu Slovenskej republiky.

Dôvod, kvôli ktorému Ústavný súd Slovenskej republiky zrušil rozhodnutie Najvyššieho súdu Slovenskej republiky, je ten, že konštatoval pochybenia tohto súdu vo vzt'ahu k vyhlasovaniu rozsudku a nejasnostiam ohl’adom postupu odstraňovania zjavných chýb v písaní a v počítaní v písomnom vyhotovení rozsudku. Ústavný súd Slovenskej republiky výslovne nekonštatoval porušenie Ústavy Slovenskej republiky napríklad vo vzt'ahu k spôsobu výpočtu pokuty. Dôvod zrušenia teda nebol konštatovaný vo vzt’ahu ku koncepcii prechodu administratívnoprávnej zodpovednosti na právneho nástupcu právnickej

68 Približne $165970 €$. 
osoby (na strane druhej treba tiež priznat', že táto skutočnost' nebola st'ažovatel'kou ani namietaná).

Otáznou však ostáva tá skutočnost', že správne súdy približne dva roky po náleze Ústavného súdu Slovenskej republiky nad’alej odkazovali vo svojej rozhodovacej praxi na zrušené súdne rozhodnutie. ${ }^{69}$ Komplexné posúdenie tejto skutočnosti zrejme prekračuje obsahový rámec tohto článku, na strane druhej však možno konštatovat', že sa domnievam, že tento postup zo strany správnych súdov možný je, a to najmä z toho hl'adiska, že právne nástupníctvo ako také nebolo predmetom ústavnej kontroly a ako také teda nebolo posúdené ako protiústavné.

Vo svetle dnešnej právnej úpravy civilného konania podl'a Správneho súdneho poriadku a Civilného sporového poriadku možno konštatovat', že v danej veci by správne súdy zrejme aplikovali čl. 4 Civilného správneho poriadku a vystupovali ako (cit.) „zákonodarca“, ${ }^{70}$ čím možno konštatovat', že rozhodnutie súdov nadobudlo istý precedenčný charakter, t. j. súdne rozhodnutie tu vystupuje ako prameň správneho práva. ${ }^{71}$

Záverom tejto state možno konštatovat', že

a) slovenská právna úprava de lege lata konštrukciu prechodu administratívnoprávnej zodpovednosti na právneho nástupcu právnickej osoby nepozná,

b) slovenská právna úprava pozná len právnu úpravu prechodu trestnoprávnej zodpovednosti na právneho nástupcu právnickej osoby,

c) napriek tomu správne orgány a správne súdy aplikovali pravidlá prechodu administratívnoprávnej zodpovednosti právnických osôb na právneho nástupcu, a to za použitia teórie o ekonomickom nástupníctve,

d) pri formulovaní odporúčaní de lege ferenda treba vychádzat' z doterajšej aplikačnej praxe správnych orgánov a správnych súdov v tejto oblasti a hl'adat' inšpiračné zdroje jednak v trestnoprávnej úprave, ako aj v zahraničnej úprave prechodu zodpovednosti.

\section{Prechod administratívnoprávnej zodpovednosti na právneho nástupcu právnickej osoby de lege ferenda na Slovensku}

Na základe predchádzajúcich analýz právnych predpisov v zahraničí, ako aj praxe slovenskej verejnej správy a správnych súdov, možno konštatovat', že z hl'adiska de lege ferenda

69 Novšie súdne rozhodnutia, ako do roku 2013, sa mi nepodarilo nájst'.

70 Podl'a čl. 4 Civilného sporového poriadku: „(1) Ak sa právna vec nedá prejednat’ a rozhodnút’ na základe výslovnébo ustanovenia tohto zákona, právna vec sa posúdi podl'a ustanovenia tobto alebo inébo zákona, ktoré upravije právnu vec co do obsabu a účlu najbližsiu posudzovanej právnej veci. (2) Ak takébo ustanovenia niet, súd prejedná a rozhodne právnu vec podl'a normy, ketorú by zvolil, ak by bol sám zákonodarcom, a to s pribliadnutim na princípy všeobecnej spravodlivosti a principy, na ktorých spočiva tento zákon, tak, aby výsledkom bolo rozumné usporiadanie procesných vat'ahov zohl'adñujuce stav a poznatky právnej náuky a ustálenú roz̧hodovaciu prax najvyššich súdnych autorit."

$71 \mathrm{~K}$ tomu pozri VRABKO, M. In: VRABKO, M. a kol. Správne právo bmotné. V šeobecná čast'. Bratislava: C. H. Beck, 2018, s. 46. 
treba uvažovat' o zavedení administratívnoprávnej zodpovednosti nástupcu právnickej osoby aj na území Slovenskej republiky. Táto právna úprava musí byt’ zachytená v predpisoch verejného práva; nestačí tu analogická úprava z civilného práva.

Možno konštatovat', že otázku, kedy môže dôjst' k hmotnoprávnej sukcesii vo vzt'ahoch verejného práva, nie je jednoduché zodpovedat'. Vo všeobecnosti sa tvrdí, že v zásade sú verejné subjektívne práva a povinnosti neprenosné, že právne skutočnosti predvídané a právne významné v súkromnom práve nemôžu založit' bez d’alšieho prechod verejnoprávnych oprávnení a povinností. ${ }^{72}$ Správny poriadok neupravuje problematiku hmotnoprávneho nástupníctva (je to záležitost' osobitných predpisov, napr. aj z oblasti občianskeho práva). Existencia osoby spôsobilej byt' nositel’om hmotných verejných subjektívnych práv alebo povinností vylučuje zastavenie správneho konania. Správny orgán pokračuje d’alej v konaní s právnym nástupcom účastníka konania. ${ }^{73}$

Vzhl'adom na to, že v oblasti správneho trestania nemožno využit' analógiu v neprospech páchatel'a, ${ }^{74}$ nemožno tiež aplikovat' problematiku právneho nástupníctva podl'a predpisov súkromného práva; takáto analógia by rozširovala podmienky deliktuálnej zodpovednosti, čo je v podmienkach právneho štátu neprípustné. Z daného dôvodu je preto nevyhnutné, aby verejnoprávny predpis upravil problematiku prechodu administratívnoprávnej zodpovednosti na právneho nástupcu právnickej osoby. Ak sa rozhodneme akceptovat' túto myšlienku, potom treba zodpovedat' niekol'ko nasledujúcich otázok.

V prvom rade treba odpovedat' na otázku, či by sa tento právny inštitút mal vzt'ahovat' na všetky správne delikty, ktorých subjektom je právnická osoba alebo nie. Ak by sa mal totiž vzt'ahovat' na všetky správne delikty, potom je vel'mi otázne, či by nešlo o právnu úpravu príliš rigidnú, a to napríklad vo vzt'ahu $\mathrm{k}$ bagatel'ným správnym deliktom, nuž a na druhej strane, ak by sa nemal vzt'ahovat' na všetky správne delikty, tak čo by malo byt' deliacim kritériom.

$\mathrm{V}$ prípade trestných činov je to jednoduchšie. Zákonodarca z diapazónu trestných činov vybral len niektoré, ktorých subjektom môže byt' právnická osoba. ${ }^{75}$ Následne na to vo vzt'ahu ku všetkým týmto trestným činom upravil aj prechod zodpovednosti.

Vo vzt’ahu k správnym deliktom to nemožno považovat' za vhodné riešenie. Verejná správa nepredstavuje „mechanizmus trestov“, ale predstavuje súhrn inštitúcií a úloh, ktorých ciel'om je podporovat' myšlienky občianskej spoločnosti, verejného záujmu, či spolupráce spravovaných subjektov navzájom a aj s vykonávatel'mi verejnej správy. Až ak tieto

72 HAMULÁKOVÁ, Z. Správne delikty právnických osôb - vybrané inštitúty a problémy. Bratislava: Wolters Kluwer, 2018, s. 253.

73 KOŠIČIAROVÁ, S. Správny poriadok. Komentár. Šamorín: Heuréka, 2013, s. 149.

74 K tomu pozri napríklad uznesenie Najvyššieho súdu Slovenskej republiky z 22. augusta 2012, sp. zn. 2Sžo/38/2011.

75 Pozri $\int 3$ TZPO; v zásade všetky tri doterajšie novely tohto zákona sa týkali práve $\int 3$ TZPO. 
myšlienky nemožno naplnit’, prichádza do úvahy využitie mocenských nástrojov, ktoré má verejná správa $\mathrm{k}$ dispozícii (tzv. princíp subsidiarity výkonu verejnej moci ${ }^{76}$ ).

Hoci by sa mohlo zdat', že v prípade porušenia právnych predpisov je už len týmto faktom ospravedlnená možnost' prechodu zodpovednosti na právneho nástupcu právnickej osoby, nie je to tak. Myslím si, že v mnohých prípadoch by išlo o neprimeraný zásah do súkromnej sféry, ktorý by mohol negatívne ovplyvnit' podnikatel'ský sektor, t. j. sektor, ktorý hrá nezanedbatel'nú úlohu vo vzt’ahu k zamestnanosti.

Môj názor je taký, že tento právny inštitút má svoje opodstatnenie a mal by sa uplatňovat' len vo vzt'ahu k zákonodarcom vymedzenému okruhu správnych deliktov. Konkrétne deliace kritérium možno ponechat' na d’alšiu diskusiu. Jedným z možných riešení by mohlo byt' vymedzenie hranice prostredníctvom sankcií za správny delikt. Konkrétne potom vo vzt'ahu k pokute, ked’že tá je ustanovená vo vzt'ahu ku každému správnemu deliktu právnickej osoby. V̌̌eobecne by sa mohla napríklad vymedzit' tak, že ak horná hranica pokuty prekročí určitú hranicu (napríklad $10000 €$ ), potom sa bude uplatňovat' aj prípadná zodpovednost' nástupcu právnickej osoby. Výhodou ustanovenia hranice prostredníctvom pokuty je aj to, že sa ňou odbúrava spomenutý problém s bagatel’nými správnymi deliktmi. Ak by nedošlo $\mathrm{k}$ takémuto všeobecnému vymedzeniu, potom sa ako d'alšia možnost' javí možnost' úpravy právneho nástupníctva vo veciach administratívnej zodpovednosti osobitne pre každý správny delikt, t. j. išlo by o úpravu vymedzenú v osobitných právnych predpisoch. Všeobecným vymedzením vo vzt'ahu k výške pokuty sa však vyhneme tomu, že by verejná správa zasahovala do súkromnej sféry nad nevyhnutnú mieru, pretože by zasiahla len spoločensky najnebezpečnejšie správne delikty. Ak by nešlo o spoločensky mimoriadne nebezpečné činy, zákonodarca by totiž nepristúpil k takým vysokým sadzbám pokuty. Navyše, týmto všeobecným spôsobom by sa zabránilo aj prípadnej „tendenčnosti“ pri vol'be správnych deliktov v prípade osobitnej právnej úpravy.

$\mathrm{V}$ rámci konkrétneho návrhu de lege ferenda možno d’alej uviest' konkrétny text právnych noriem, ktoré by zakladali zodpovednost' právneho nástupcu. Text právnych noriem by bol sformulovaný vo viacerých odsekoch. Vychádzal som pri jeho formulovaní jednak z myšlienok o právnom nástupníctve, ale modifikovanom aj ideami o ekonomickom nástupníctve. Toto sú závery, ku ktorým som dospel.

Prvý odsek by mohol byt' formulovaný takto: „Zodpovednost' za správny deliket právnickej osoby, ktorá zanikla, prechádza na jej právneho nástupcu; to plati aj pre nevykonanú sankciu pokuty. Ak má právnická osoba viac právnych nástupcov, zodpovedá za správny delikt každý z nich. Pri vol'be drubu sankcie a jej výmery je správny orgán povinný pribliadnut' aj na to, v akom rozsahu prešli na právneho nástupcu výnosy, úvítky a iné výhody zo spáchanébo správneho deliktu a na to, č pokračuje niektorý z.právnych nástupcov v činnosti, pri ktorej bol správny deliket spáchany.““

76 Pozri bližšie HORVAT, M. In: CEPEK, B. a kol. Správne právo hmotné. V šeobecná čast’. Bratislava: Wolters Kluwer, 2017, s. 70-71. 
Ide o všeobecné ustanovenie, ktoré upravuje prechod zodpovednosti na právneho nástupcu. Podstatou tohto ustanovenia je prelomenie zásady totožnosti páchatel’a a sankcionovanej osoby. Z ustanovenia vyplýva, že sa nemožno zbavit’ zodpovednosti poukázaním na to, že došlo k zániku právnickej osoby. Dôvodom je skutočnost', že právna zodpovednost' prechádza na právneho nástupcu a prechádza na neho ex lege. Rovnako si treba povšimnút', že prechádza na každého právneho nástupcu, nielen na niektorých. Ustanovenie vychádza z princípu objektívneho prechodu zodpovednosti na právneho nástupcu bez ohladu na to, či právny nástupca vedel (mohol vediet') o spáchaní správneho deliktu právnickou osobou a ktorý je predmetom správneho konania.

Treba si taktiež uvedomit’, že aj v prípade „ret’azenia“ zánikov právnických osôb zodpovednost' za správny delikt prechádza na d'alších právnych nástupcov. Ak preto spoločnost' X zanikla a jej právnym nástupcom je spoločnost' Y, ktorá následne zanikla s právnym nástupcom Z, tak zodpovednost' prešla z pôvodnej spoločnosti X na spoločnost' Z. ${ }^{77}$

Ustanovenie počíta aj s možnost'ou zániku právnickej osoby po právoplatnom rozhodnutí o vine, kde správny orgán uloží ako sankciu pokutu. V takom prípade prechádza zodpovednost' za vykonanie sankcie pokuty na právneho nástupcu. Bližšie je tento aspekt vymedzený v nasledovnom navrhovanom odseku.

Odsek rovnako vymedzuje aj zásadu primeranosti vo vzt’ahu k zásade individualizácie sankcie. Sankcia ako taká by vždy mala postihovat' výsostne páchatel’a. V prípade prechodu zodpovednosti to tak nie je, a preto je nevyhnutné, aby v rámci individualizácie sankcie vo vzt’ahu ku konkrétnym skutkovým zisteniam, správny orgán prihliadol aj na to, že sankciu ukladá právnemu nástupcovi a nie priamo páchatelovi. Správny orgán by musel kumulatívne prihliadnut' na dve skutočnosti, a to:

a) prechod výnosov, úžitkov a iných výhod na právneho nástupcu (má sa tu na mysli v podstate akýkol'vek ekonomický prospech z protiprávnej činnosti, najmä vecí, a to bez ohl'adu na ich hmotnú alebo nehmotnú podobu),

b) pokračovanie v činnosti, v súvislosti s ktorou bol spáchaný správny delikt (nemá sa tu na mysli vyslovene len pokračovanie v protiprávnej činnosti, ale pokračovanie v akejkol’vek činnosti, ktorá má súvis so spáchaným správnym deliktom, a to vrátane činnosti povolenej ${ }^{78}$ ).

77 Z obdobnej myšlienky vychádza aj TZPO. Uvádza sa, že trestná zodpovednost' je upravená tak, že prechádza na všetkých právnych nástupcov vždy, pokial došlo k právnemu nástupníctvu, a to bez ohl’adu na to, či v okamihu vzniku právneho nástupníctva právnickej osoby alebo právnických osôb boli vôbec začaté úkony trestného konania, ked’že táto skutočnost' je na prechod trestnej zodpovednosti právnickej osoby na právneho nástupcu, ku ktorému dochádza ex lege, úplne bez významu (ČENTÉŠ, J. In: TURAYOVÁ, Y., L. TOBIÁŠOVÁ a kol. Trestná zodpovednost právnickýych osôb. Medzinárodné a európskee aspekty, právnoteoretické východiská. Bratislava: Univerzita Komenského v Bratislave, 2014, s. 132).

78 Porovnaj ZÁHORA, J. In: ZÁHORA, J. a I. ŠIMOVČEK. Zákon o trestnej zodpovednosti práunických osôb. Komentár. Bratislava: Wolters Kluwer, 2016, s. 182. 
Práve $\mathrm{v}$ tejto časti právnej normy vychádzam aj z ekonomického chápania právneho nástupníctva, ktoré tiež bude povinne skúmat’ správny orgán pri svojom rozhodovaní. Vychádzam tu, okrem iného, aj z myšlienok Z. Kiselyovej, podl'a ktorej stojí za úvahu, či by teória ekonomického nástupníctva, ktorá vychádza z európskej i vnútroštátnej judikatúry, nemala byt' korektívom, resp. zákonným dôvodom (alebo jedným zo zákonných dôvodov) vo vzt’ahu k upusteniu od potrestania. To znamená, že správny orgán by pri posudzovaní možnosti upustenia od potrestania prihliadol na to, či je právny nástupca ekonomickým nástupcom pôvodne zodpovednej právnickej osoby, ked’ prebral materiálne aj l'udské zdroje a pokračuje v ekonomických aktivitách svojho predchodcu, a to takým spôsobom, aby bol zároveň naplnený účel zákona, ktorý upravuje skutkovú podstatu správneho deliktu, ktorý bol porušený právnym predchodcom. ${ }^{79}$

Druhý odsek by mohol byt' formulovaný nasledovne: „Ak právnická osoba, ktorá správny deliket spáchala, zanikla ažpo právoplatnosti roz̧odnutia o vine a uloženi sankcie, prechádza povinnost' vykonat' sankiu pokuty na právneho nástupcu zaniknutej právnickej osoby. Ak je právnych nástupcov niekol'ko, za vykonanie sankcie pokuty zodpovedajú spoločne a nerozdielne. Na návrh právneho nástupcu právnickej osoby môže správny orgán, ktorý o sankecii rozhodol v prvom stupni, rozbodnút', ci a v akom rozsahu sa vat'ahuje povinnost' vykonat' sankeciu pokuty aj na tohto právneho nástupcu."

Predmetné ustanovenie rieši situáciu, ked’ bola uložená sankcia, avšak po právoplatnom rozhodnutí o jej uložení, došlo k zániku právnickej osoby. Z dôvodu, aby sa právnická osoba nevyhla povinnosti vykonat' danú sankciu, je nevyhnutné upravit' pravidlo o prechode zodpovednosti za vykonanie uloženej sankcie aj na právneho nástupcu. Vykonat' by bolo možno len sankciu pokuty, ked’že sa stotožňujem so záverom, že vykonanie iných druhov sankcií právnym nástupcovmu v správnom práve by bolo neefektívne.

Ak je právnych nástupcov niekol'ko, vychádza toto ustanovenie z myšlienky o vzniku solidárneho záväzku právnych nástupcov k povinnosti uhradit' pokutu.

Ďalej sa tu precizuje aj skutočnost', že právny nástupca nie je páchatelom a napriek tomu ho postihne sankcia pokuty. Z tohto dôvodu sa zavádza možnost' právneho nástupcu iniciovat' správne konanie, ktorým by sa prípadný prechod povinnosti vykonat' uloženú sankciu voči nemu alternoval. Išlo by o správne konanie, kde vecná príslušnost' by bola priznaná tomu správnemu orgánu, ktorý vo veci rozhodoval v prvom stupni. Postupovalo by sa podl'a všeobecných pravidiel Správneho poriadku, a preto by voči rozhodnutiu tohto orgánu bol prípustný riadny opravný prostriedok.

79 KISELYOVÁ, Z. In: MASLEN, M. a N. HRNČĆROVÁ (eds.). Trestnoprávna a administratívnoprávna zodpovednost'. Trnava: Typi Universitatis Tyrnaviensis, 2014, s. 117. Uvedené myšlienky tejto autorky som však neaplikoval vyslovene na upustenie od potrestania, ale na otázky spojené s ukladaním sankcie. Je len zrejmé, že pokial’ tu nie je ekonomický „,súvis“, správny orgán nebude trestat’ právneho nástupcu v plnom rozsahu, ale túto skutočnost' zohl'adní, pričom ak by chcel pristúpit’ k upusteniu od potrestania, mohol by, avšak túto skutočnost' by musel upravit' zákon expressis verbis $\mathrm{v}$ rámci ustanovení o ukladaní sankcií. 
Tretí odsek by mohol byt' formulovaný nasledovne: „Štatutárny orgán právnickej osoby alebo jeho člen, proti ktorej je vedené správne konanie o správnom delikte, je povinný bez meškania písomne oblásit’ príslušnému správnemu orgánu začatie vykonávania právnych úkonov alebo vænik právnych skutočností,

a) k.toré môzư spôsobit' zánik obvinenej právnickej osoby alebo

b) mỗ̌u mat' väčsi vplyv na majetok obvinenej právnickej osoby. "

Ustanovenie ukladá dve povinnosti štatutárnemu orgánu právnickej osoby počas správneho konania o obvinení zo spáchania správneho deliktu. Ide o informačné povinnosti. Ciel'om je zabezpečit' prípadný budúci výkon rozhodnutia o vine a sankcii právnickej osoby. Povinnost' sa týka skutočností, ktoré môžu mat' za následok zánik obvinenej právnickej osoby alebo ktoré môžu mat' väčš́ vplyv na vymožitel'nost' pokuty alebo náhrady škody. Na výklad pojmu „väčší vplyv“ bude treba vychádzat’ z okolností konkrétneho prípadu; nie je vylúčené prihliadnut' alternatívne na pojem škoda, ktorý je definovaný Trestným zákonom. ${ }^{80} \mathrm{Na}$ zabezpečenie vymožitel'nosti tohto ustanovenia sa následne navrhuje v odseku 4, aby nesplnenie týchto povinností bolo priestupkom. Vo vzt'ahu k týmto povinnostiam treba ešte dodat', že systematicky súvisia aj s navrhovaným odsekom pät'.

Štvrtý odsek by mohol byt' formulovaný nasledovne: „Nesplnenie povinnosti podl'a odseku 3 je priestupkom, za ktorý môže správny orgán uložit’ pokutu až do výšky XYZ eur. Na prejednávanie priestupkov sa vžt'ahuje v̌̌eobecný predpis o priestupkoch. "

S ciel'om zabezpečenia plnenia povinností podl'a odseku 3 sa navrhuje, aby nesplnenie tam uvedených povinností, bolo možné sankcionovat'. Ako typ správneho deliktu som zvolil priestupok, hoci možno uvažovat' aj o správnom poriadkovom delikte. Som však toho názoru, že zákon o priestupkoch by mal byt' všeobecným právnym predpisom vo vzt'ahu k vyvodzovaniu administratívnej zodpovednosti fyzických osôb. Ak by išlo o správny poriadkový delikt, postupovalo by sa podl'a ustanovení Správneho poriadku, avšak Správny poriadok nemožno považovat' za vhodný právny predpis, pokial ide o vyvodzovanie zodpovednosti.

Pozitívom tohto ustanovenia je aj skutočnost', že vyvodit' zodpovednost' voči štatutárnemu orgánu právnickej osoby alebo jeho členovi možno aj v prípade, ak dôjde k zániku právnickej osoby, osobitne ak k nemu dôjde bez právneho nástupcu. Výšku pokuty v texte právnej normy ponechávam na d’alšiu diskusiu. Nevylučujem možnost' jej určenia napríklad zlomkom k sadzbám pokuty, ktorá mohla byt' uložená právnickej osobe.

80 Podl’a \ 125 ods. 1 Trestného zákona sa malou škodou rozumie škoda prevyšujúca sumu $266 €$. Škodou väčšou sa rozumie suma dosahujúca najmenej desat'násobok takej sumy. Značnou škodou sa rozumie suma dosahujúca najmenej stonásobok takej sumy. Škodou vel'kého rozsahu sa rozumie suma dosahujúca najmenej pät’stonásobok takej sumy. Tieto hl'adiská sa použijú rovnako na určenie výšky prospechu, hodnoty veci a rozsahu činu. 
Piaty odsek by mohol byt' formulovaný nasledovne: „Ak zistené skutočnosti nasvedčujú tomu, že obvinená právnická osoba je páchatelom správneho deliktu a zjej konania alebo konkrétnych skutočnosti vyplýva, že sa z̧bavi svojho majetku a obrozi tým výkon sankcie pokuty, môže správny orgán roz̧odnút' o uloženi zaist'ovacieho opatrenia; odvolanie (rozklad) voči roz̧odnutiu správneho orgánu o zaist'ovanom opatreni nemá odkladný účnok. Na účly tobto ustanovenia sa za zaist'ovacie opatrenie považuje

a) povinnost' Zložit' peñažnú sumu alebo vec do úschovy správneho orgánu alebo

b) zákaz nakladat's určitými vecami alebo právami. “

Tento odsek reaguje na skutočnost', že správny orgán nemá vo svojej kompetencii schval’ovanie právnych úkonov, ktorých ciel’om je zánik právnickej osoby, ako je to v prípade trestného konania voči právnickej osobe. ${ }^{81}$ Zároveň toto ustanovenie sa odchyl’uje od právnej úpravy v Českej republike, ktorá toto umožňuje. Takáto právomoc totiž vzhl’adom na skutočnost', že orgány verejnej správy nie sú budované na princípoch nezávislosti a nestrannosti, je, podl'a môjho názoru, neprimeraným zásahom do práv súkromných osôb. Na druhej strane správny orgán musí mat’ k dispozícii určité nástroje, ktorými zabezpečí efektivitu správneho konania o trestnom obvinení právnickej osoby, a to aj v prípade, ak tá začne uskutočňovat' úkony smerujúce k jej zániku alebo k zníženiu hodnoty jej majetku.

Konkrétne ide o nástroje uvedené v písmenách a) a b). Ide o zaist'ovacie opatrenia, ktorých podstata spočíva $\mathrm{v}$ obmedzení možnosti nakladania s majetkom právnickej osoby. ${ }^{82}$ Význam tohto ustanovenia možno vidiet' aj v tom, že vhodne zvolené zaist'ovacie opatrenie zabezpečí efektívnost' aj vo vzt'ahu k zániku právnickej osoby bez právneho nástupcu.

Zaist'ovacie opatrenie by bolo ukladané podl'a všeobecných pravidiel o správnom konaní, t. j. podl’a Správneho poriadku, s možnost'ou uplatnenia riadneho opravného prostriedku voči nemu. Ustanovuje sa, aby podaný riadny opravný prostriedok voči zaist’ovaciemu opatreniu nemal odkladný účinok. Zaist'ovacie opatrenie by bolo možné uložit' kedykol'vek počas priebehu správneho konania, vrátane konania o riadnom opravnom prostriedku. Správny orgán je oprávnený uložit’ aj obe zaist’ovacie opatrenia súbežne v jednom rozhodnutí alebo aj vo viacerých.

Šiesty odsek by mohol byt' formulovaný nasledovne: „Zodpovednost' za správny deliket právnickej osoby neprechádza na fyzickú osobu. "

V určitom zmysle slova ide o poistku. Aj ked’ z logiky veci vyplýva, že zodpovednost' nemôže prejst’ z osoby právnickej na osobu fyzickú a naopak, považujem za vhodné, aby toto pravidlo bolo zakotvené aj expressis verbis v právnej úprave. Vychádzam tu najmä

81 Pozri \ 25 ods. 2 TZPO.

82 Porovnaj ŠIMOVČEK, I. In: ZÁHORA, J. a I. ŠIMOVČEK. Zákon o trestnej zodpovednosti právnickejich osôb. Komentár. Bratislava: Wolters Kluwer, 2016, s. 302. 
zo skutočnosti, že aj fyzická osoba môže prevziat' podnik právnickej osoby, t. j. ide tu o situácie, ked’ fyzická osoba prevezme imanie obvinenej právnickej osoby. ${ }^{83}$

Aj ked’ navrhnuté riešenie zániku zodpovednosti za správny delikt v dôsledku zániku právnickej osoby určite nie je bez chýb a určite nedáva odpoved’ na všetky otázky, ${ }^{84}$ som toho názoru, že umožňuje v základoch preklenút' negatíva $\mathrm{v}$ podobe nemožnosti vyvodit' zodpovednost' vôbec. Uznávam, že týmto spôsobom dochádza k prelomeniu tradičnej zásady individuálnej zodpovednosti, avšak zároveň treba pripomenút', že protiprávna činnost' právnických osôb je spoločensky nebezpečnou činnost'ou, a preto treba aj de lege lata riešit' situácie, ako jednoducho obíst' vyvodenie zodpovednosti voči týmto subjektom.

Som toho názoru, že predložené návrhy formulovaných právnych noriem spĺňajú požiadavky, ktoré boli vymedzené jednak analyzovanými rozhodnutiami správnych súdov, požiadavky kladené medzinárodnými dohovormi, ako aj požiadavky právnej teórie a právnej praxe.

Záverom by bolo vhodné uviest' ešte určité zovšeobecnenia vyplývajúce z predchádzajúceho textu, pričom som sa inšpiroval myšlienkami J. Bejčka. V rámci vyvodzovania zodpovednosti za správny delikt právnickej osoby treba vychádzat’ primárne z toho, že zodpovednost' nesie ten, kto sa protiprávneho konania dopustil. Zároveň platí, že zmena právnej formy alebo názvu páchatel’a ho nemôže zbavit' právnej zodpovednosti, právne zodpovedným ostane predajca právnickej osoby v prípade, ak po predaji právnickej osoby táto stále existuje. ${ }^{85}$

\section{Záver}

Administratívnoprávna zodpovednost' právnických osôb je témou, ktorá rozhodne nesmie „ostat' v tieni““ vyvodzovaniu zodpovednosti voči fyzickým osobám. Práve táto zodpovednost’ je totiž ešte menej legislatívne upravená, než v prípade fyzických osôb, osobitne priestupkov. Právna prax preto musí často siahat' po menej štandardných krokoch pri jej vyvodzovaní, pričom často sa stáva, že neexistuje žiadna právna regulácia, ktorá by praktický problém dokázala vyriešit'.

83 Pozri \88a Obchodného zákonníka.

84 Možno napríklad spomenút' situácie, ked’ k zániku spoločnosti dochádza ex lege a nie v dôsledku právnych úkonov spoločníkov spoločnosti; napríklad ak bola právnická osoba založená len na určitý čas, alebo na konkrétny účel, ktorý dosiahla. Český zákon č. 418/2011 Sb. o trestní odpovědnosti právnických osob a řízení proti nim uvedené rieši expressis verbis takto: „Byla-li právnická osoba založena na dobu určitou nebo k dosaženi určitébo účelu, a v dobè od zahájeni jejího trestního stíbáni uplynula doba, na nižz byla založena, nebo se naplnil úcel, pro keterý byla založena, hledi se na ni od tohoto okamžileu, jako by byla založena na dobu neurčitou. "Slovenský TZPO obdobnú úpravu nepozná.

85 Porovnaj stat' s BEJČEK, J. Veřejný zájem, procesní nástupnictví a spravedlnost aneb „,fiat lex (in stricto nonsensu), pereat iustitia?“. In: Právní roz̧hledy, 2008, roč. 16, č. 12, s. 444-445. 
Jedným z týchto právnych problémov pri vyvodzovaní zodpovednosti voči právnickým osobám je aj prechod administratívnoprávnej zodpovednosti na právneho nástupcu právnickej osoby. Prekladaný článok si kládol za ciel’ vyplnit' medzeru v tejto oblasti, pričom na základe analýzy pôvodu myšlienok prechodu právnej zodpovednosti na právneho nástupcu právnickej osoby, právnej úpravy štátov, ktoré túto problematiku majú legislatívne upravenú a praktických prípadov, kedy sa správne orgány a správne súdy stretli s vyvodením zodpovednosti voči právnemu nástupcovi, dospel k záverečným odporúčaniam.

Spomenuté odporúčania sa pretavili v podobe jednak pozitívnej odpovede na otázku, či by mala slovenská legislatíva upravit' prechod administratívnoprávnej zodpovednosti na právneho nástupcu právnickej osoby, ako aj na konkrétne možné znenie textu právneho predpisu, ktorý by túto problematiku upravil.

Pevne verím, že aj ked’ iste tento článok nedáva odpoved’ na všetky otázky spojené $\mathrm{s}$ touto témou, tak že svojim dielom prispeje $\mathrm{k}$ pokračovaniu a prehíbeniu odbornej vedeckej diskusie na túto problematiku. 